\title{
Long term effects of manure, charcoal and mineral fertilization on crop production and fertility on a highly weathered Central Amazonian upland soil
}

\author{
Christoph Steiner • Wenceslau G. Teixeira • Johannes Lehmann • \\ Thomas Nehls • Jeferson Luis Vasconcelos de Macêdo • \\ Winfried E. H. Blum • Wolfgang Zech
}

Received: 16 September 2006 / Accepted: 2 January 2007 / Published online: 2 February 2007

(C) Springer Science+Business Media B.V. 2007

\begin{abstract}
Application of organic fertilizers and charcoal increase nutrient stocks in the rooting zone of crops, reduce nutrient leaching and thus improve crop production on acid and highly weathered tropical soils. In a field trial near Manaus (Brazil) 15 different amendment combinations based on equal amounts of carbon (C) applied through chicken manure (CM), compost, charcoal, and forest litter were tested during four cropping cycles with rice (Oryza sativa L.) and sorghum (Sorghum bicolor L.) in five replicates. $\mathrm{CM}$ amendments resulted in the highest $(P<0.05)$ cumulative crop yield $\left(12.4 \mathrm{Mg} \mathrm{ha}^{-1}\right)$ over four seasons. Most importantly, surface soil $\mathrm{pH}$, phosphorus $(\mathrm{P})$, calcium $(\mathrm{Ca})$, and magne-
\end{abstract}

C. Steiner $(\bowtie) \cdot$ T. Nehls $\cdot$ W. Zech

Institute of Soil Science and Soil Geography,

University of Bayreuth, 95440 Bayreuth, Germany

e-mail: Christoph.Steiner@uni-bayreuth.de

W. G. Teixeira · J. L. V. de Macêdo

Embrapa Amazonia Ocidental, CP 319,

Manaus, AM, 69011-970, Brazil

J. Lehmann

Department of Crop and Soil Sciences,

Cornell University, Ithaca, NY, 14853, USA

W. E. H. Blum

Institute of Soil Research,

University of Natural Resources and Applied Life

Sciences (BOKU), 1180 Vienna, Austria sium $(\mathrm{Mg})$ were significantly enhanced by CM. A single compost application produced fourfold more grain yield $(P<0.05)$ than plots mineral fertilized in split applications. Charcoal significantly improved plant growth and doubled grain production if fertilized with NPK in comparison to the NPK-fertilizer without charcoal $(P<0.05)$. The higher yields caused a significantly greater nutrient export in charcoal-amended fields, but available nutrients did not decrease to the same extent as on just mineral fertilized plots. Exchangeable soil aluminum (Al) was further reduced if mineral fertilizer was applied with charcoal (from 4.7 to $0 \mathrm{mg} \mathrm{kg}^{-1}$ ). The resilience of soil organic matter (SOM) in charcoal amended plots ( 8 and $4 \%$ soil $\mathrm{C}$ loss, mineral fertilized or not fertilized, respectively) indicates the refractory nature of charcoal in comparison to SOM losses over 20 months in CM (27\%), compost amended (27\%), and control plots ( $25 \%$ loss).

Keywords Black carbon - Brazil ·

Organic agriculture $\cdot$ Oxisol $\cdot$ Terra Preta de Indio

\section{Introduction}

Slash and burn agriculture is practiced by about 300-500 million people globally, affecting almost one third of the planet's 1,500 million ha of arable land (Giardina et al. 2000; Goldammer 1993). 
This traditional agricultural practice is considered to be sustainable if adequate fallow periods (up to 20 years) are following a short time of cultivation (Kleinman et al. 1995). A growing population with changing socio-economic habits may not be able to practice slash and burn in a sustainable way. In most agricultural systems the tendency has been for population pressure to increase, leading to shorter fallow periods (Fearnside 1997). Significant amounts of nutrients, mainly nitrogen (N) and sulfur (S) (Giardina et al. 2000; Hölscher et al. 1997a; Hughes et al. 2000; Kuhlbusch et al. 1991), and organic matter (OM) are lost by burning forests during the conversion of native vegetation to pasture or crop land. Accelerated OM loss through burning disrupts soil organic matter (SOM) formation and extended cultivation periods further reduce the SOM contents correlating with soil nutrient depletion (Goldammer 1993; Hölscher et al. 1997b; Silva-Forsberg and Fearnside 1995; Zech et al. 1990). In strongly weathered tropical soils, SOM plays a major role in soil productivity (Tiessen et al. 1994) because it represents the dominant reservoir of plant nutrients such as $\mathrm{N}, \mathrm{P}$, and S. Generally, SOM contains $95 \%$ or more of the total $\mathrm{N}$ and $\mathrm{S}$, and between 20 and $75 \%$ of the $\mathrm{P}$ in surface soils (Duxbury et al. 1989). Thus, longterm intensive land use where SOM stocks are depleted, is not sustainable without nutrient inputs (Tiessen et al. 1994). On soils with lownutrient retention capacity the strong tropical rains easily leach available and mobile nutrients, such as inorganic $\mathrm{N}$ fertilizers, rapidly into the subsoil where they are unavailable for most crops (Giardina et al. 2000; Hölscher et al. 1997a; Renck and Lehmann 2004) rendering conventional fertilization highly inefficient.

Reducing losses of nutrients and $\mathrm{C}$ resulting from forest clearing require alternatives to slash and burn (Lewis et al. 2002) and alternative fertilization methods. Depending on the mineralization rate, organic fertilizers such as compost, mulch or manure release nutrients in a gradual manner (Burger and Jackson 2003) and may therefore be more appropriate for nutrient retention under high-leaching conditions than inorganic fertilizers. But, as mentioned above, not only nutrients but also $\mathrm{C}$ from the vegetation and soils is lost over time during deforestation and subsequent land use. Such a $\mathrm{C}$ loss reduces the ability of the soil to retain nutrients especially in soils with low-activity clays such as in highly weathered soils of the humid tropics (Sanchez 1976).

Application of charred biomass as an alternative to manures or composts seems to be a promising option to maintain a maximum of $\mathrm{C}$ in soils as charring significantly increases the stability of $\mathrm{C}$ against microbial decay (Baldock and Smernik 2002). However, charcoal represents just $1.7 \%$ of the pre-burn biomass if a forest is converted by the traditional slash and burn technique (Fearnside et al. 2001). The purposeful production of charcoal for soil application is able to increase the proportion that can be applied in such shifting cultivation systems (Lehmann et al. 2006).

The existence of an anthropogenic and Cenriched dark soil in different parts of the world and especially in Amazonia (Amazonian Dark Earths (ADE) or Terra Preta de Indio) makes it likely that a similar strategy existed before the arrival of the Europeans. Without steel axes and modern tools for deforestation it is more likely that soil fertility was maintained by the Amazon Indians with rich organic inputs instead of clearing new forests when soil fertility decreased (Denevan 1996). The ADE's fertility is most likely linked to an anthropogenic accumulation of $\mathrm{P}$ and $\mathrm{Ca}$ associated with bone apatite (Lehmann et al. 2004; Lima et al. 2002; Zech et al. 1990) and black C as charcoal (Glaser et al. 2001a). The high persistence of charcoal is responsible for the stability of the ADE's SOM. Today and as assumed also in the past those soils have been intensively cultivated by the native population. The existence of ADE proves that infertile Oxisols can in principle be transformed into fertile soils. However, this transformation was not solely achieved by replenishing the mineral nutrient supply, but relies on the addition of stable $\mathrm{C}$ in the form of charcoal.

The sustained fertility in charcoal-containing ADE and the frequent use of charcoal as a soil conditioner (Steiner et al. 2004b) in Brazil and other parts of the world (mainly Japan) Ogawa (1994) provided the incentive to study the effects of charcoal application to a highly weathered soil 
(Lehmann et al. 2003). Lehmann et al. (2002) and Steiner et al. (2004b) described slash and char as an alternative agricultural method producing charcoal from the aboveground biomass instead of converting it to $\mathrm{CO}_{2}$ through burning. Slash and char practiced as an alternative to slash and burn throughout the tropics could be an important step toward sustainability by SOM conservation in tropical agriculture. Therefore, we addressed the following objectives: (1) to quantify the effects of charcoal, organic, and inorganic fertilization on soil fertility and crop production; and (2) to evaluate the sustainability of charcoal additions in terms of maintaining high-SOM contents and nutrient availability with special emphasis on Terra firme Ferralsols near Manaus. It is hypothesized that charcoal additions improve nutrient availability and that crop productivity is maintained on a higher level than without charcoal additions.

\section{Materials and methods}

The experiment was established $30 \mathrm{~km}$ north of Manaus, Amazonas, Brasil ( $3^{\circ} 8^{\prime} \mathrm{S}, 59^{\circ} 52^{\prime} \mathrm{W}, 40$ $50 \mathrm{~m}$ a.s.l.) at the Embrapa-Amazônia Ocidental (Empresa Brasileira de Pesquisa Agropecuaria) experimental research station. The natural vegetation is evergreen tropical rainforest with a mean annual precipitation of 2,530 mm (1971-1997) having its seasonal maximum between December and May, a mean annual temperature of $25.8^{\circ} \mathrm{C}$ (1987-1997) and a relative humidity of $85 \%$ (Correia and Lieberei 1998). After clearing of about $3,600 \mathrm{~m}^{2}$ secondary forest and removing the aboveground biomass the experiment was established on a highly weathered Xanthic Ferralsol (FAO 1990) derived from Tertiary sediments. The soil is fine textured with up to $80 \%$ clay. It is strongly aggregated and has medium contents of organic C $\left(24 \mathrm{~g} \mathrm{~kg}^{-1}\right)$, low-pH values of 4.7 (in $\mathrm{H}_{2} 0$ ), low CEC of $1.6 \mathrm{cmol}_{\mathrm{c}} \mathrm{kg}^{-1}$ and low-base saturation $(\mathrm{BS})$ of $11.2 \%$.

About 15 randomized treatments were applied on $4 \mathrm{~m}^{2}$ plots $\left(2 \times 2 \mathrm{~m}^{2}\right)$ in five replicates forming an entire field area of $1,600 \mathrm{~m}^{2}\left(45 \times 35 \mathrm{~m}^{2}\right)$ with a minimum distance to the surrounding vegetation of $10 \mathrm{~m}$. The plots were protected against runoff water by metal sheets. Rice was planted into the spaces between plots as an active barrier in order to decrease the risks of cross contamination by runoff.

\section{Charcoal amendments (2CC)}

Charcoal amendments were considered rather as soil conditioner than fertilizer due to the charcoal's low-nutrient contents (Table 1). Previous pot experiments revealed advantageous effects of soil charcoal amendments in addition to any direct nutrient additions (Lehmann et al. 2003). Terra Preta research has shown that oxidation on the edges of the aromatic backbone and adsorption of other OM to charcoal is responsible for the increased CEC, though the relative proportion of these two processes is unclear (Liang et al. 2006).

Charcoal derived from secondary forest wood, was bought from a local distributor. It was manually crushed to particle sizes smaller than $2 \mathrm{~mm}$. The applied $11 \mathrm{mg} \mathrm{ha}^{-1}$ charcoal corresponded to the amount of charcoal-C which could be produced by a single slash-and-char event of a typical secondary forest on Xanthic Ferralsols in central Amazonia (Lehmann et al. 2002). The amount of $\mathrm{C}$ added with charcoal was chosen as a reference value for adding the compost, litter, and chicken manure (CM) amendments.

\section{Mineral fertilization (F)}

Mineral fertilizer (NPK and lime) was applied as ammonium sulfate $\left(\left(\mathrm{NH}_{4}\right)_{2} \mathrm{SO}_{4}\right)$, simple super phosphate, and potassium chlorite $(\mathrm{KCl})$ as recommended by Embrapa (Fageria 1998). In addition to one solely inorganically fertilized treatment (F) all organically treated plots despite $\mathrm{CM}$ and litter (L) had one replicate with additional inorganic fertilization. Mineral fertilizer was applied in March 2001 and after the second harvest in April 2002 (Table 1). At the second fertilization the treatments $\mathrm{L}$, and $2 \mathrm{CCp}+\mathrm{CO}+\mathrm{F}$ were additionally fertilized with micronutrients (Table 1). Those treatments received mineral fertilization for the first time. While the $2 \mathrm{CCp}+\mathrm{CO}+\mathrm{F}$ treatment with micronutrients was paired with one treatment without micronu- 


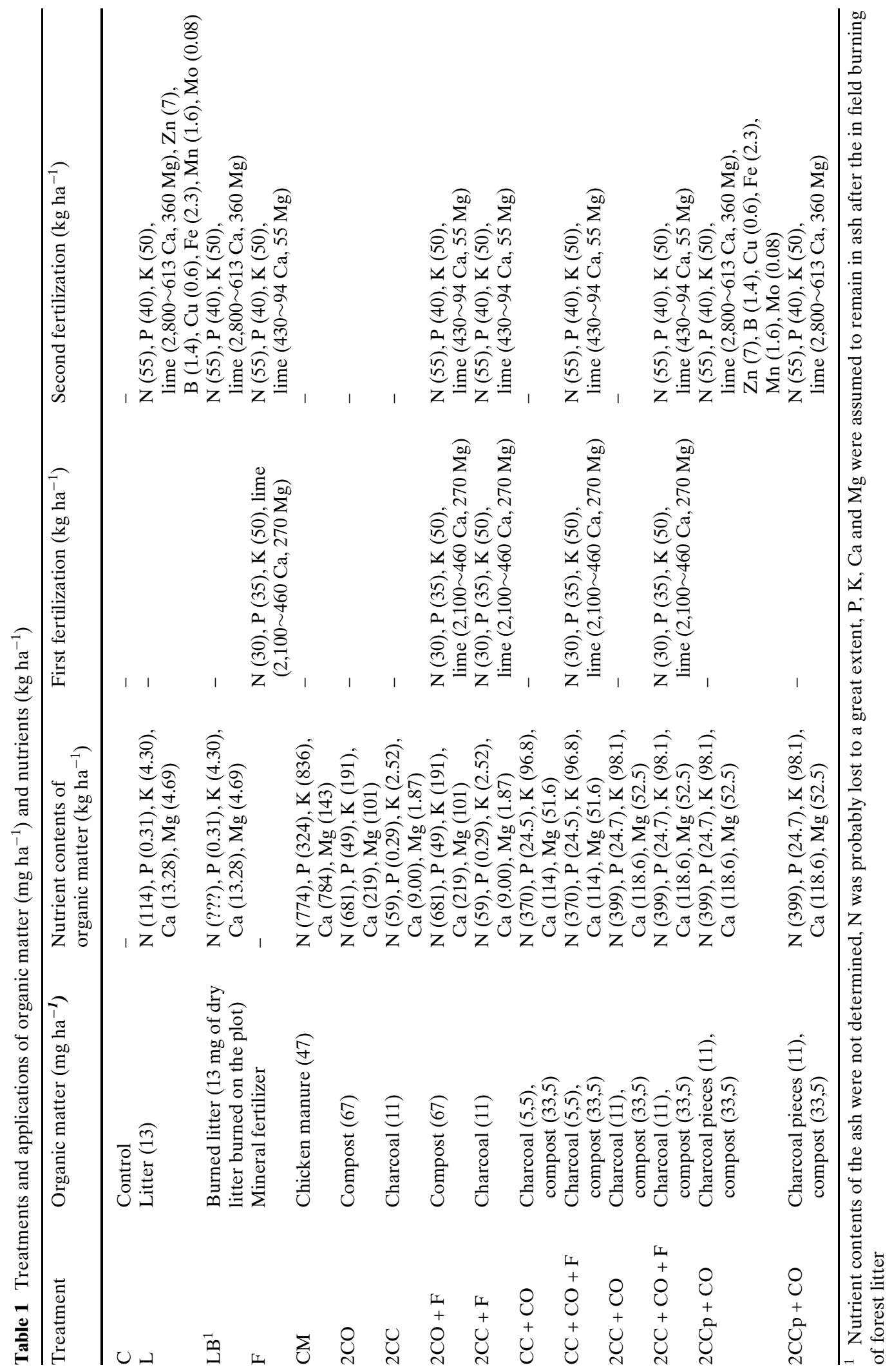


trients, the litter treatment was not identically paired, but the treatments $\mathrm{C}, \mathrm{L}$, and burned litter (LB) did not show any differences at the first harvest and had no biomass production at all at the second harvest.

Organic amendments (L, LB, CM, 2CO)

Organic materials were applied just once at the beginning of the experiment (February 3, 2001). The amount of applied OM (litter, L; CM; compost, 2CO; and leaf litter, L) was calculated from the total $\mathrm{C}$ content of the materials to increase total soil $\mathrm{C}$ content in $0-10 \mathrm{~cm}$ depth by $25 \%$. Compost was prepared from biomass of a secondary forest, fruit residues, manure, and kitchen waste. The CM was bought at a nearby chicken farm and the litter was collected on the experimental site. From February 12-20, 2001, the fields were hoe-harrowed to $0.10 \mathrm{~m}$ depth and the organic amendments were mixed in with the soil. LB was established with the intention to simulate slash and burn farming. Unburned litter (L) was of interest in order to study alternative cultivation without burning (slash and mulch). Compost and $\mathrm{CM}$ are available organic fertilizers. Compost is rather expensive in Manaus but could be produced by land-owners themselves. CM is abundant due to a large poultry industry in the vicinity of Manaus and therefore relevant for land-owners.

Combination treatments $(\mathrm{CC}+\mathrm{CO}, 2 \mathrm{CC}+\mathrm{CO}$, $\mathrm{CCp}+\mathrm{CO})$

Combination treatments were established to study the effects of organic nutrients applied together with charcoal. Carbon was applied above the reference value (1.5 times) if the full charcoal dose $(2 \mathrm{CC}=$ reference value $)$ was applied as a degree of comparison. All combination treatments were established with and without mineral fertilization. Charcoal applied as pieces $(\sim 10 \mathrm{~mm}$ in diameter) instead of powdered charcoal $(<2 \mathrm{~mm})$ was used to study the effect of charcoal size. A combination of CM and charcoal was missing in this study, but was studied in other experiments (Steiner et al., unpublished).
Crops

As a first crop rice (Oryza sativa L.) was planted followed by three repeated sorghum (Sorghum bicolor L. Moench) crops. Rice was planted March 10, 2001 in a density of 200 seeds per $\mathrm{m}^{2}$, followed by sorghum planted on October 15, 2001 in a density of 12.5 plants per $\mathrm{m}^{2}$. The $3 \mathrm{rd}$ crop was established in a density of 25 plants per $\mathrm{m}^{2}$ on April 18, 2002, the latter producing two harvests by ratooning. The stover and grain yields were assessed on July 7, 2001, February 6, 2002, July 21, 2002, and October 16, 2002. To minimize border effects, two plant rows were left at each harvest on each side of the plots. The plant material was stored in paper bags and immediately dried at $65^{\circ} \mathrm{C}$ until constant weight. Rice grains and straw were weighed separately. Biomass samples were ground with a ball mill and stored for nutrient analysis. The dried and weighed crop residues were brought back to the plots of origin and remained on the field for decomposition. Only the ground plant samples $(\sim 10 \mathrm{~g})$ for foliar nutrient analyses were removed from the system.

Soil samples and sample analyses

Soil samples (at depths of $0-0.1,0.1-0.3$, and $0.3-$ $0.6 \mathrm{~m}$ ) were taken at the beginning of the experiment (after OM application but before mineral fertilization) and later on after each harvest (February 23, 2001, July 11, 2001, February 15, 2002, July 23, 2002, and November 22, 02). Two samples per plot were taken, combined to one composite sample, and then air dried and sieved to pass $2 \mathrm{~mm}$.

For the determination of foliar nutrient contents a digestion with a mixture of $\mathrm{H}_{2} \mathrm{SO}_{4}$, salicylic acid, $\mathrm{H}_{2} \mathrm{O}_{2}$, and selenium was used according to Walinga (1995). For the extraction of exchangeable $\mathrm{P}, \mathrm{K}, \mathrm{Ca}$, and $\mathrm{Mg}$, the Mehlich-3 extraction was used without modification (Mehlich 1984). Calcium and $\mathrm{Mg}$ in the filtered solutions were analyzed using atomic absorption spectrometry (AA1475, Varian Associates, Inc., Palo Alto, CA, USA). Potassium was analyzed with a flame photometer (Micronal B 262, Sao Paulo, SP, Brazil). Phosphorus was measured using a photometer

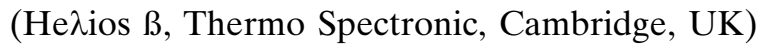



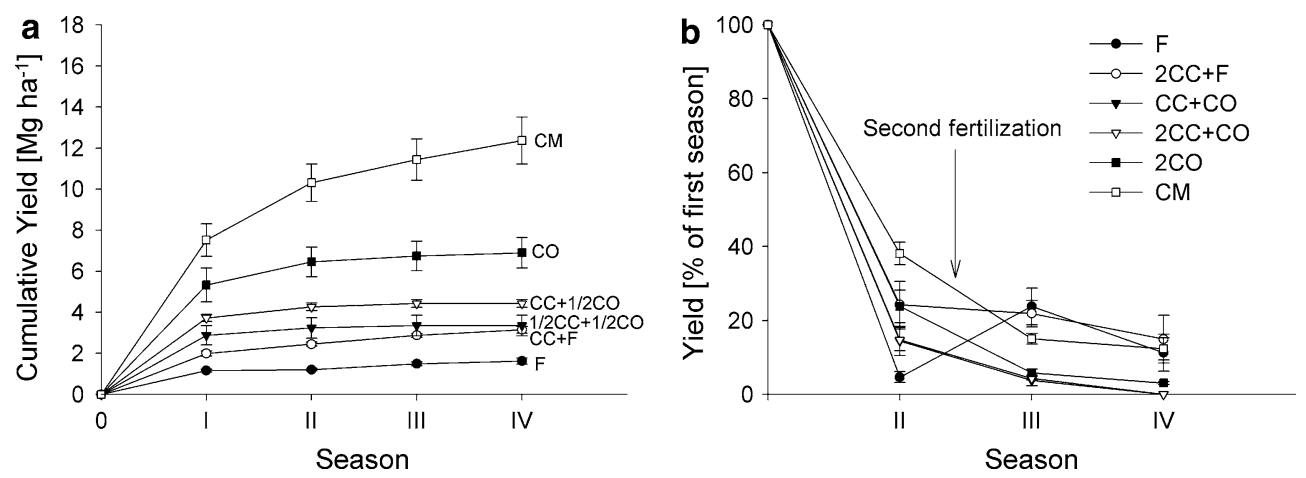

Fig. 1 a Cumulative yields of selected treatments and $\mathbf{b}$ the yields as a percentage of the yield at first harvest. Mineral fertilization without any OM input is indicated by an arrow (means and standard errors; $N=5$ )

with the molybdene blue method (Olsen and Sommers 1982). pH was determined in water and $1 \mathrm{~N} \mathrm{KCl}(1: 5 \mathrm{w} / \mathrm{v})$ using an electronic $\mathrm{pH}$ meter with a glass electrode (WTW pH 330, WTW, Weilheim, Germany) and electric conductivity by a conductivity meter (HI 8733, HANNA Instruments, Kehl am Rhein, Germany). Total C and N were analyzed by dry combustion with an automatic C/N- Analyzer (Elementar, Hanau, Germany).

Plant-available $\mathrm{NH}_{4}$ and $\mathrm{NO}_{3}$ were determined photometrically in soil extracts (in $1 \mathrm{~N} \mathrm{KCl)} \mathrm{using}$ a rapid flow analyzer (Scan Plus analyzer, Skalar Analytical B.V., Breda, The Netherlands). Exchangeable acidity and exchangeable Al were determined by titration (McLean 1965) after extraction with $1 \mathrm{~N} \mathrm{KCl}$. Cation exchange capacity was calculated as the sum of ammonium acetate-exchangeable cations and acidity (Claessen et al. 1997).

\section{Statistical analyses}

Treatment effects were analyzed by general linear model (GLM) univariate analysis of variance (ANOVA). Most parameters were not normally distributed and did not have equal variances. For refitting a Box Cox transformation (Box and Cox 1964) was used. Homogeneous subsets were separated by the Student-Newman-Keuls test and the Fisher's LSD (least significant difference) was inserted into figures. Statistical analyses and plots were performed using SPSS 12.0 and SigmaPlot (SPSS Inc., Chicago, IL, USA).

\section{Results}

Stover and grain yield

Total cumulative stover production (all harvests) decreased in the order $\mathrm{CM}>2 \mathrm{CO}+\mathrm{F}>2 \mathrm{CO}=$ $2 \mathrm{CC}+\mathrm{CO}+\mathrm{F}=\mathrm{CC}+\mathrm{CO}+\mathrm{F}>\mathrm{CCp}+\mathrm{CO}=2 \mathrm{C}$ $\mathrm{C}+\mathrm{F}>2 \mathrm{CC}+\mathrm{CO}=\mathrm{CC}+\mathrm{CO}=\mathrm{F}>\mathrm{L}=\mathrm{LB}>2$ $\mathrm{CC}>\mathrm{C}$. Cumulative grain yield showed similar results, but the difference between charcoal containing plots to plots without charcoal was even greater than for total stover. Mineral fertilized plots with additional charcoal application had almost twice as much yield as only mineral fertilized plots (Fig. 1a). CM proved to be the most effective treatment within this experiment. Total grain yield (all harvests together $12.4 \mathrm{Mg} \mathrm{ha}^{-1}$, Fig. 1a) and total stover production (14.2 $\mathrm{Mg} \mathrm{ha}^{-1}$ ) were significantly higher than that of the other treatments, aside from a combined compost, and mineral fertilizer application (10.6, $11.6 \mathrm{Mg} \mathrm{ha}^{-1}$ for yield and stover production, respectively). The productivity of only minerally fertilized plots $(F)$ declined rapidly after the first harvest (Fig. 1b).

\section{First harvest}

Organic and mineral fertilization increased the stover production (leaves and stalks) and grain yield of rice ( $O$. sativa L.). The highest stover production was achieved with a combination of compost and mineral fertilizer $\left(6.24 \mathrm{Mg} \mathrm{ha}^{-1}\right)$ while the greatest grain yield was harvested using $\mathrm{CM}$ 
(7.5 $\mathrm{Mg} \mathrm{ha}^{-1}$, Fig. 1). Charcoal alone and litter (L) applications alone had a minor effect. LB and charcoal amendments significantly improved yields compared to control and unburned litter although with very little grain production $(0.18$, $0.10,0.01$, and $0.02 \mathrm{Mg} \mathrm{ha}^{-1}$, respectively). Stover and grain yield production were increased by 29 and $73 \%$, respectively if mineral fertilizer was applied on plots with charcoal in comparison to mineral fertilization alone (Fig. 1).

Second harvest

No plant growth was found in control, charcoal, litter, and LB plots. Plots fertilized with CM had the highest $(P<0.05)$ grain yield and stover production $\left(2.80,3.56 \mathrm{Mg} \mathrm{ha}^{-1}\right)$, followed by fields receiving compost + mineral fertilizer (1.59, $\left.1.51 \mathrm{Mg} \mathrm{ha}^{-1}\right)$ and only compost (1.13, $1.11 \mathrm{Mg} \mathrm{ha}^{-1}$, respectively). While charcoal additions alone did not affect crop production, a synergistic effect occurred when both charcoal and inorganic fertilizers were applied. The grain yield and stover production was 0.05 and $0.27 \mathrm{Mg} \mathrm{ha}^{-1}$, respectively, within plots receiving inorganic fertilizer, $0.0 \mathrm{Mg} \mathrm{ha}^{-1}$ within plots receiving charcoal and 0.46 and $0.72 \mathrm{Mg} \mathrm{ha}^{-1}$, respectively, within plots receiving both amendments (Fig. 2). Stover production on plots receiving charcoal plus mineral fertilizer $(2 \mathrm{CC}+\mathrm{F})$ was found to be in the same homogenous subgroup as compost-treated plots. Bare mineral fertilization had the smallest effect on grain yield and stover production. The synergistic effects of charcoal in combination with fertilizers improved yields by a factor of 9 and the stover production by a factor of 2.7 in comparison to only mineral fertilized plots (Fig. 2). In addition, a visible difference was observed in plant growth during this cropping period. Plants growing on $2 \mathrm{CC}+\mathrm{F}$ were 24.7 and $42.0 \mathrm{~cm}$ tall whereas plants growing on F-plots were only 13.0 and $21.8 \mathrm{~cm}$ tall after 50 and 55 days, respectively $(P<0.001, N=80)$.

\section{Third and fourth harvest}

Crop production with added CM still exceeded those with all other applications (yield 1.13, 0.93, stover 3.05, $1.64 \mathrm{Mg} \mathrm{ha}^{-1}$, 3rd and 4th harvest,

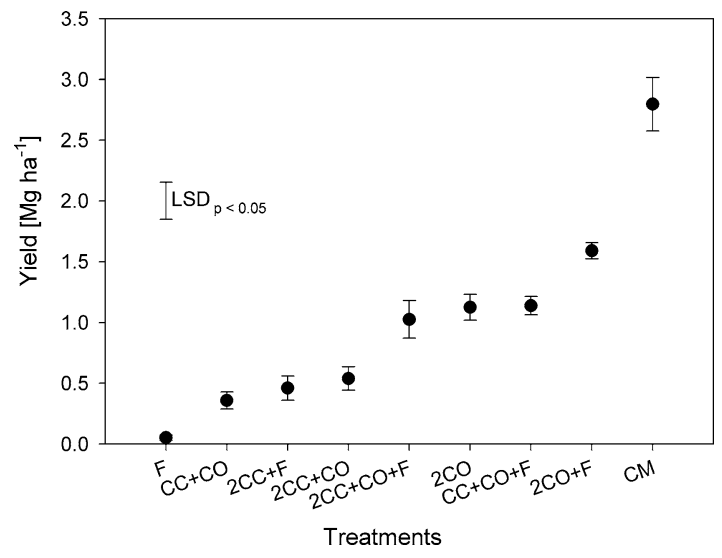

Fig. 2 Grain yield production at the second harvest (February 06,2002$)$. The error bars show the mean \pm standard error. The Fisher's least significant difference $(L S D)$ value is plotted to scale significant mean separation $(P<0.05)$

respectively). Plots receiving $\mathrm{CC}+\mathrm{CO}$ always produced less biomass than the $2 \mathrm{CC}+\mathrm{CO}$ plots. This difference was significant at the 3rd harvest and at the 4 th harvest where the CC treatment ceased to produce any biomass. Mineral fertilizer with additional charcoal or compost application again improved stover production and yield. Although the synergistic effect of charcoal plus mineral fertilizers was less than observed at the 2nd harvest, it still improved yield and stover production by a factor of 1.5 and 2.0 for yield and 1.3 and 1.4 for stover at the 3rd and 4th harvest, respectively. Only three out of five plots produced grain yield at the 4 th harvest if only mineral fertilized. The application of micronutrients after the 2 nd harvest (Table 1) did not show any significant effect $(P>0.05)$, indicating that the observed charcoal effect was not caused by the charcoal's micronutrient content (data not shown).

Nutrient contents of plants and grains

The plants fertilized with $\mathrm{CM}$ had the highest nutrient contents followed by plants that received compost and/or mineral fertilizer. CM significantly improved the $\mathrm{K}$ and $\mathrm{P}$ nutrition in comparison to all other treatments. Charcoal applications did not show a significant influence on nutrient levels. Only the foliar K contents of crop residues originating from plots receiving 

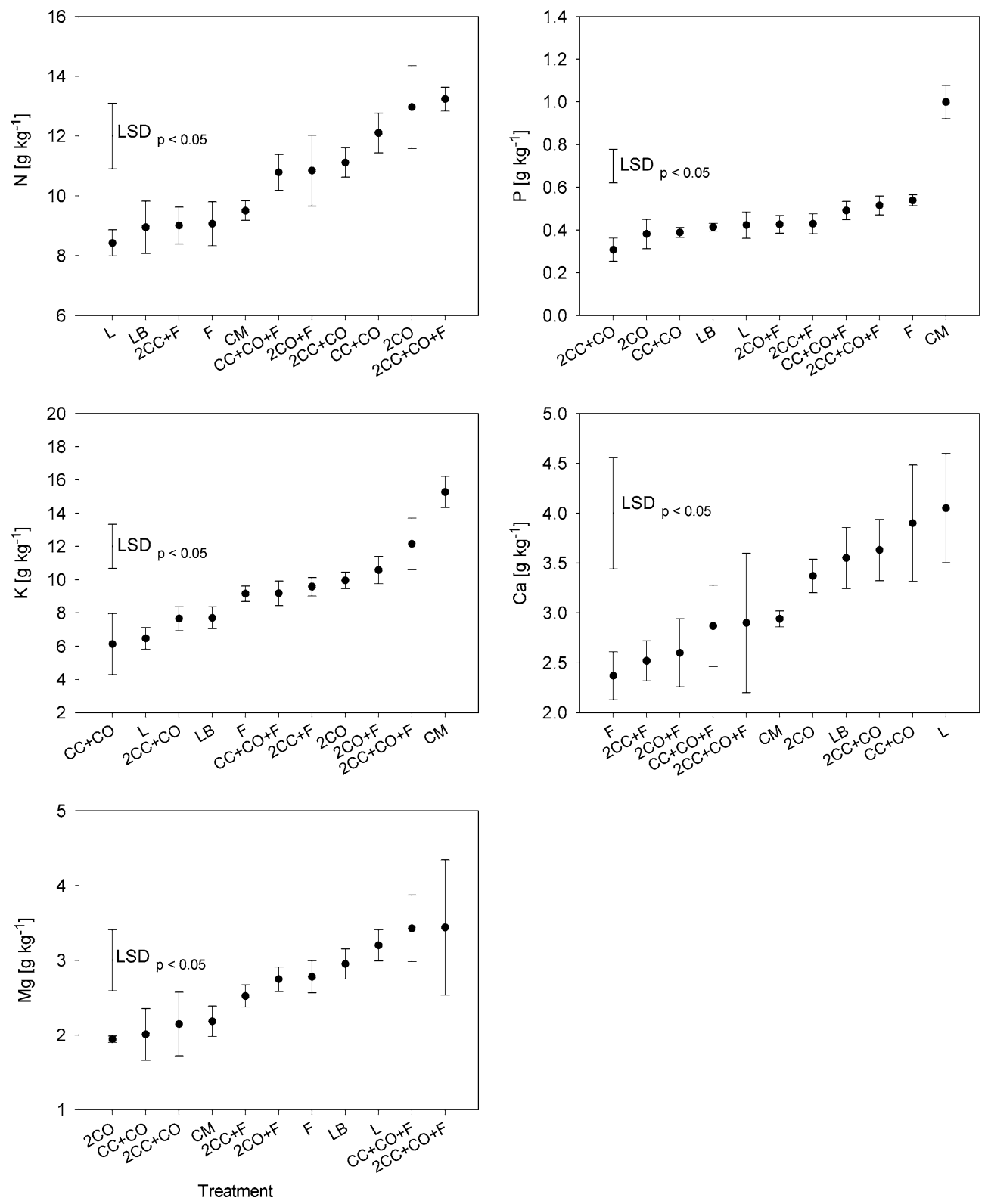

Fig. 3 Foliar nutrient contents in crop residues of the 3rd harvest. The error bars show the mean \pm standard error. The Fisher's least significant difference $(L S D)$ value is plotted to scale significant mean separation $(P<0.05)$

charcoal and mineral fertilizer were higher than those on plots with mineral fertilizer alone. After the 3rd harvest similar results were obtained. Although mineral fertilization was repeated, plants growing on $\mathrm{CM}$ plots still had significantly $(P<0.05)$ higher $\mathrm{P}$ and $\mathrm{K}$ contents compared to all other treatments (Fig. 3). Plots amended with compost or compost plus charcoal but without mineral fertilizer revealed the high- est foliar $\mathrm{N}$ levels although producing significantly less biomass.

Mainly $\mathrm{P}$ and $\mathrm{N}$ were exported due to a higher content of these elements in grains than crop residues, which remained on the plots. In contrast, crop residues generally contained approximately $90 \%$ of the $\mathrm{K}$ and $\mathrm{Ca}$. The exported $\mathrm{K}$ after the first harvest due to the removal of grains was almost twice as much on fertilized plots plus 

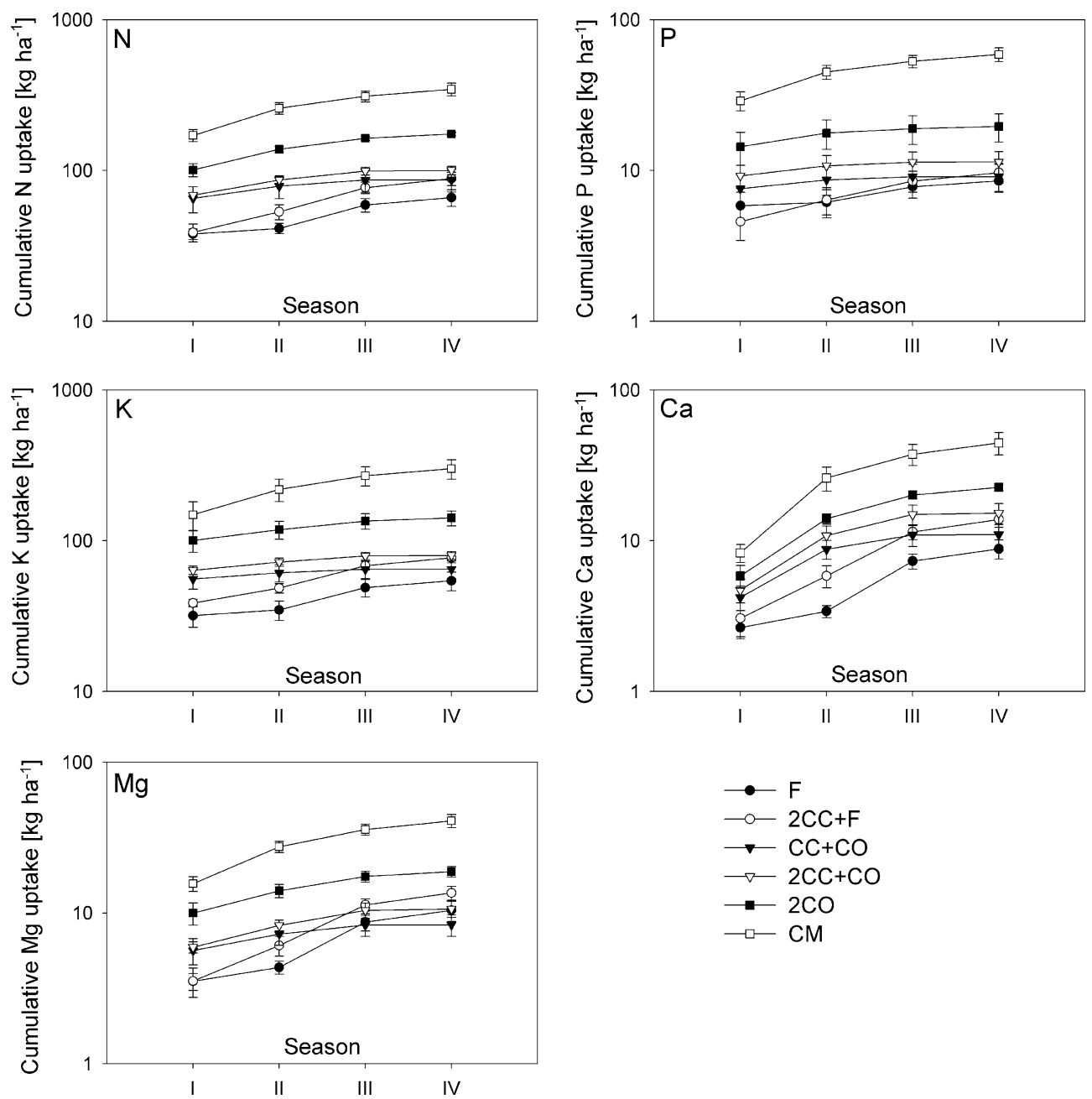

Fig. 4 Cumulative nutrient uptake (grains and crop residues) of selected treatments on a logarithmic scale (means and standard errors; $N=5$ )

charcoal addition $(2 \mathrm{CC}+\mathrm{F})\left(2.83 \mathrm{~kg} \mathrm{ha}^{-1}\right)$ compared to only minerally fertilized plots (F) $\left(1.42 \mathrm{~kg} \mathrm{ha}^{-1}\right)$. After the second harvest almost tenfold more nutrients $(\mathrm{K}, \mathrm{Ca}, \mathrm{Mg}, \mathrm{P}$, and $\mathrm{N}$ ) were exported from $2 \mathrm{CC}+\mathrm{F}$-plots $\left(2.8 \mathrm{~kg} \mathrm{ha}^{-1} \mathrm{~K}\right.$, $1.0 \mathrm{~kg} \mathrm{ha}^{-1} \mathrm{Ca}, 0.7 \mathrm{~kg} \mathrm{ha}^{-1} \mathrm{Mg}, 1.5 \mathrm{~kg} \mathrm{ha}^{-1} \mathrm{P}$, and $\left.7.5 \mathrm{~kg} \mathrm{ha}^{-1} \mathrm{~N}\right)$ than on F-plots $\left(0.3 \mathrm{~kg} \mathrm{ha}^{-1} \mathrm{~K}\right.$, $0.1 \mathrm{~kg} \mathrm{ha}^{-1} \mathrm{Ca}, 0.1 \mathrm{~kg} \mathrm{ha}^{-1} \mathrm{Mg}, 0.2 \mathrm{~kg} \mathrm{ha}^{-1} \mathrm{P}$, and $0.8 \mathrm{~kg} \mathrm{ha}^{-1} \mathrm{~N}$ ) due to their higher yields (Fig. 4). The $\mathrm{P}$ export after the following harvests continued to be significantly higher from the charcoal plots. The overall $\mathrm{K}$ export with grains from $2 \mathrm{CC}+$ F-plots $\left(9.2 \mathrm{~kg} \mathrm{ha}^{-1} \mathrm{~K}\right)$ during the four cropping seasons was significantly higher in comparison to F-plots $\left(4.2 \mathrm{~kg} \mathrm{ha}^{-1} \mathrm{~K}\right)$.
Soil nutrient contents (Fig. 5, Table 2)

\section{Mineral fertilization}

Soil samples after mineral fertilization were taken after the first harvest. A significant enhancement through mineral fertilization was achieved by liming. The $\mathrm{Ca}\left(210 \mathrm{mg} \mathrm{kg}^{-1}\right)$ and $\mathrm{Mg}\left(77 \mathrm{mg} \mathrm{kg}^{-1}\right)$ levels significantly increased in the surface soil layer $(0.1 \mathrm{~m})$ of all mineral fertilized plots but this had only little effect on $\mathrm{pH}$. Extractable $\mathrm{Al}$ contents $\left(4.7 \mathrm{mg} \mathrm{kg}^{-1}\right)$ significantly decreased in comparison to the control plots $\left(63.8 \mathrm{mg} \mathrm{kg}^{-1}\right)$.

The Al concentrations were further decreased $(P<0.05)$, if mineral fertilizer was applied on 

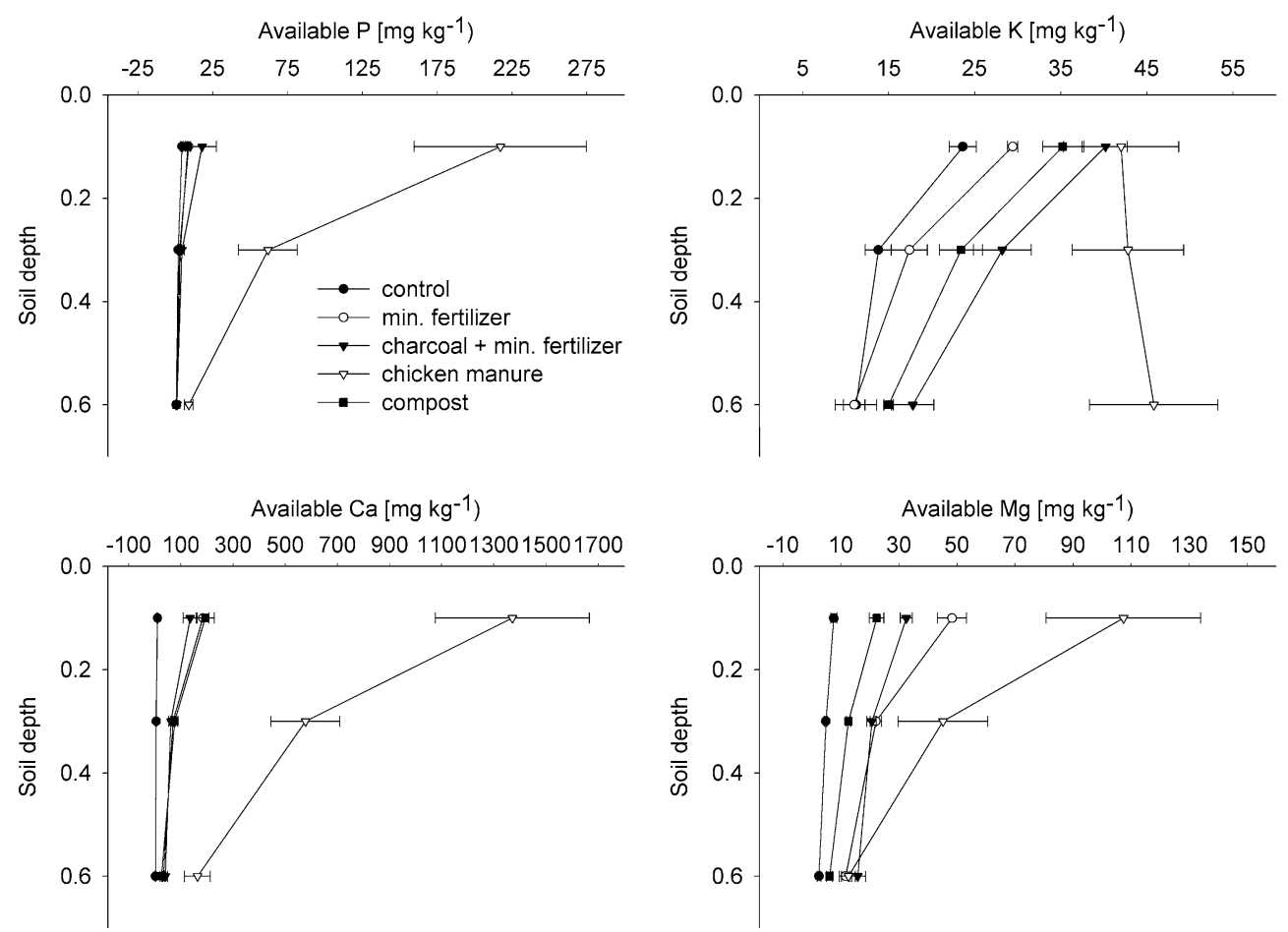

Fig. 5 The influence of selected treatments on plant available $\mathrm{P}, \mathrm{K}, \mathrm{Ca}$, and $\mathrm{Mg}$ down to a soil depth of $0.6 \mathrm{~m}$. Soil samples were taken after the 3 rd harvest (means and standard errors; $N=5$ )

charcoal containing plots. Mineral fertilization significantly increased BS but CEC was not significantly altered.

After the second harvest the mineral fertilized plots had less available $\mathrm{P}, \mathrm{K}, \mathrm{Ca}$, and $\mathrm{Mg}$ (2.2, $20.4,74.6$, and $43.5 \mathrm{mg} \mathrm{kg}^{-1}$ ) than those plots that received additional charcoal $(4.5,24.2,86.6$, and $45.9 \mathrm{mg} \mathrm{kg}^{-1}$ ) although the differences were not significant. Even though significantly more nutrients ( $\mathrm{P}, \mathrm{K}, \mathrm{Ca}, \mathrm{Mg}$, and $\mathrm{N}$ ) were exported from the charcoal plots the available soil nutrient contents of the soil did not decrease in comparison to only mineral fertilized plots. By the end of the experiment (after the 4th harvest) $2 \mathrm{CC}+\mathrm{F}$-plots still revealed higher nutrient availability and higher nutrient exports due to grain removal in comparison to F-plots (data not shown).

\section{Organic amendments}

Compost significantly increased soil nutrient contents, mainly $\mathrm{P}, \mathrm{K}, \mathrm{Ca}$, and $\mathrm{Mg}$ as the compost contained lime. Only a very small and not significant increase in soil nutrient contents resulted from charcoal, litter or LB application. LB showed significantly increased $\mathrm{NH}_{4}$ contents.

Nutrient concentrations were several fold higher (top $0.1 \mathrm{~m})$ on $\mathrm{CM}$ plots $\left(\mathrm{N}_{\text {min }}\right.$ $112 \mathrm{mg} \mathrm{kg}^{-1}$, P $610 \mathrm{mg} \mathrm{kg}^{-1}, \mathrm{~K} 1,108 \mathrm{mg} \mathrm{kg}^{-1}$, Ca $\left.2,793 \mathrm{mg} \mathrm{kg}^{-1}, \quad \mathrm{Mg} 373 \mathrm{mg} \mathrm{kg}^{-1}\right)$ than the amounts measured on control plots $\left(\mathrm{N}_{\min }\right.$ $27 \mathrm{mg} \mathrm{kg}^{-1}$, P $3 \mathrm{mg} \mathrm{kg}^{-1}, \mathrm{~K} \quad 32 \mathrm{mg} \mathrm{kg}^{-1}$, Ca $16 \mathrm{mg} \mathrm{kg}^{-1}, \mathrm{Mg} 11 \mathrm{mg} \mathrm{kg}^{-1}$ ) and enhanced the plant-available $\mathrm{P}, \mathrm{K} \mathrm{Ca}$, and $\mathrm{Mg}$ contents down to a soil depth of $60 \mathrm{~cm}$ (Fig. 5). Also pH was significantly increased and reached almost neutral levels (6.6).

Soils of the CM plots continued to show the highest nutrient contents after the first harvest (Table 2). No available Al was found in the top $10 \mathrm{~cm}$ when $\mathrm{CM}$ or charcoal + mineral fertilizer were added. A significant increase in CEC was only found in soils fertilized with $\mathrm{CM}$ and the acidity was further reduced.

After the 3rd harvest $\mathrm{P}, \mathrm{Ca}$, and $\mathrm{Mg}$ contents remained high on $\mathrm{CM}$ plots but $\mathrm{K}$ contents 


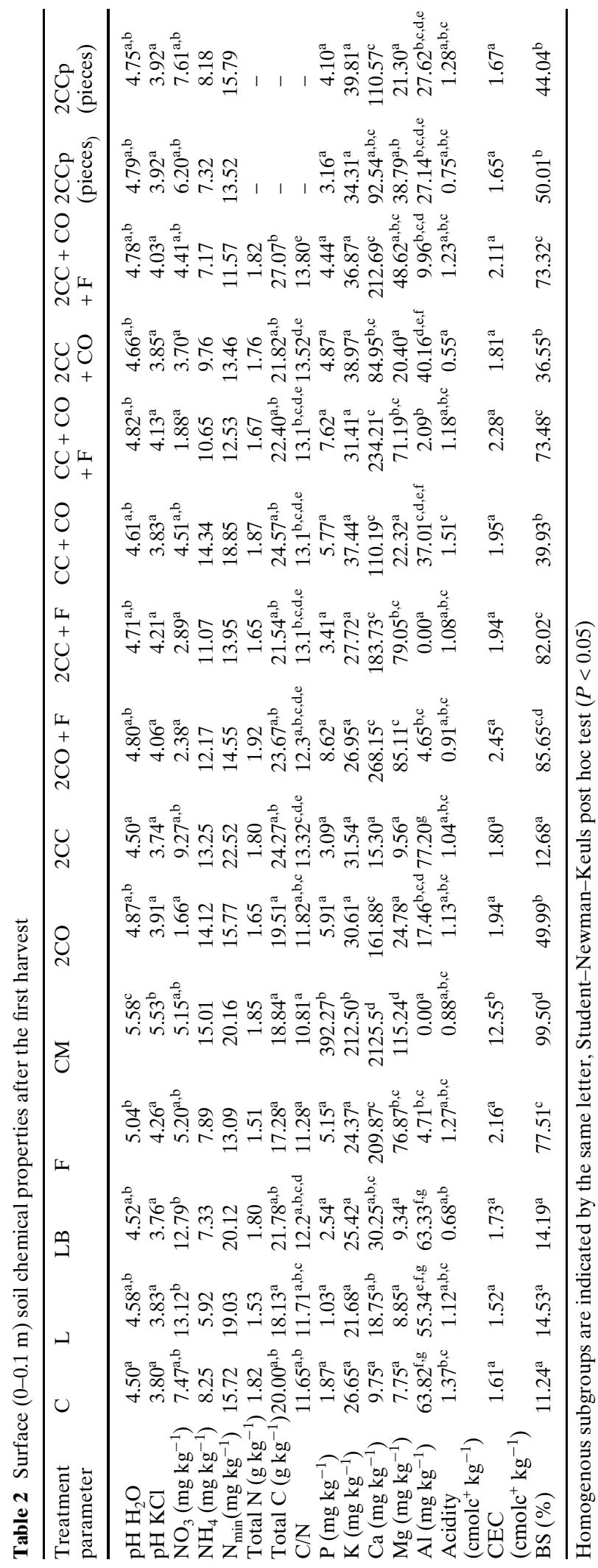


decreased. CM fertilized plots had significantly lower acidity $\left(0.03 \mathrm{cmolc}^{+} \mathrm{kg}^{-1}\right)$ than all other treatments.

\section{Soil carbon dynamics}

Total soil C contents increased due to OM application. The initial charcoal application significantly increased the $\mathrm{C} / \mathrm{N}$ ratio. This difference to plots without charcoal remained detectable by the end of the experiment. Although $\mathrm{N}$ was fertilized twice, the total $\mathrm{N}$ content of the soil remained rather stable and was even reduced to a greater extent in plots not containing charcoal. Soils receiving charcoal lost only $11 \%$ of their initial soil $\mathrm{C}$ and $13 \%$ of total $\mathrm{N}$ in comparison to $23 \%$ of $\mathrm{C}$ and $23 \%$ of $\mathrm{N}$ on plots without charcoal regardless of mineral fertilization. Even the control and mineral fertilized plots without any OM additions lost 25 and $22 \%$ of $\mathrm{C}$, respectively. In contrast plots receiving just charcoal or charcoal plus mineral fertilizer (without compost) lost only 4 and $8 \%$ of their soil $\mathrm{C}$ content even at a higher starting level.

\section{Discussion}

\section{Charcoal amendments}

Charcoal appeared to be more stable than the other tested organic amendments as well as the native SOM. Charcoal containing soil lost only 8 and $4 \%$ of their soil $\mathrm{C}$ content with or without mineral fertilization, respectively, in contrast to organic fertilization (compost or CM) where soil $\mathrm{C}$ content decreased by $27 \%$. Even the control plots had a mean soil $\mathrm{C}$ loss of $25 \%$. The resilience of soil $\mathrm{C}$ in charcoal amended plots shows the refractory nature of charcoal (Kuhlbusch and Crutzen 1995). While the stability of charcoal leads to low-C losses, nutrient release by mineralization is most likely lower than from other organic materials. The recalcitrant nature of charcoal and low-nutrient contents (Table 1 for total $\mathrm{N}$ and available $\mathrm{P}, \mathrm{K}, \mathrm{Ca}$, and $\mathrm{Mg}$ contents) therefore makes charcoal itself unlikely to be a balanced fertilizer. According to Duxbury et al. (1989) and Sombroek et al. (1993) it is important to separate effects due to $\mathrm{OM}$ per se (maintenance and improvement of water infiltration, water holding capacity, structure stability, CEC, healthy soil biological activity) from those due to its decomposition (source of nutrients).

A further assumption from Terra Preta research is that slow oxidation on the edges of the aromatic backbone of charcoal forming carboxylic groups is responsible for both the potential of forming organo-mineral complexes and the increased CEC (Glaser et al. 2001b). The period of this study might not have been sufficient for oxidation. Cheng et al. (2006) demonstrated in an incubation experiment that already 4 months at $30^{\circ} \mathrm{C}$ could significantly increase the CEC. Possibly, the amount of applied charcoal was insufficient to increase the CEC as observed in our study (Table 2). According to Duxbury et al. (1989) much of the negative charge is not expressed in soils, both because it is $\mathrm{pH}$ dependent and because many of the negatively charged sites are blocked by interactions with Al. SOM was only effective at increasing CEC levels above $\mathrm{pH} 5.5$, which is consistent with blockage of exchange sites by either $\mathrm{Al}$ or $\mathrm{Fe}$ at lower $\mathrm{pH}$ values (Lobes and Cos, 1977 cited in Duxbury et al. 1989). In our study only plots fertilized with CM had $\mathrm{pH}$ values higher than 5.5 and increased CEC. Much higher charcoal amendments increased $\mathrm{pH}$ in a pot experiment by Lehmann et al. (2003) using the same soil as studied in this experiment. Again the amount of charcoal applied in our experiment might not have been high enough to find statistically significant changes in soil $\mathrm{pH}$.

The conditions of ADE are ideal for maximum biological $\mathrm{N}_{2}$ fixation. About $77 \%$ of the ADE sampled showed positive incidence of Azospirillum spp. compared to only $10 \%$ of the Ferralsols (Silvester-Bradley et al. 1980). Charcoal provides a good habitat for the propagation of useful microorganisms such as free-living nitrogen fixing bacteria and mycorrhizal fungi (Ogawa 1994). Ogawa (1994) holds the charcoal's weak alkalinity, porosity, and ability to retain water and air responsible for the stimulation of microbes.

We found the largest biomass differences during the second harvest, which was also the driest cropping cycle. The mean daily precipitation was $6 \mathrm{~mm}$, 
which is $2 \mathrm{~mm}$ less than during the first cropping cycle. Even more important is the uneven distribution of rainfall during the second growth season. More than one quarter of the $700 \mathrm{~mm}$ fell during one single rain event in a few hours and up to 8 days free of precipitation occurred. Both Duxbury et al. (1989) and Sombroek et al. (1993) emphasize the importance of OM for the maintenance and improvement of water infiltration and water holding capacity. Glaser et al. (2002) concluded from a literature survey that only sandy soils had higher available moisture after charcoal additions, clayey soils even showed decreased moisture contents with increasing charcoal additions.

\section{Mineral fertilization}

Mineral fertilization resulted in a fast depletion of soil nutrients and a rapid decline in grain yields after the first cropping cycle (Fig. 1b). These findings corroborate the conclusion of Zech et al. (1990) that solely a replenishment of plant-available nutrients by mineral nutrient additions is not enough to maintain soil fertility in freely draining soils. Because SOM is often the major source of negative charge in tropical soils, its maintenance is important for the adsorption of exchangeable cations (Duxbury et al. 1989). In a study conducted by Lehmann et al. (1999) $63 \%$ of the $\mathrm{N}$ applied as $\left(\mathrm{NH}_{4}\right)_{2} \mathrm{SO}_{4}$ was lost from the top $1.2 \mathrm{~m}$ by leaching and volatilization, but just $1 \%$ of the organically applied $\mathrm{N}$ (from mulch). Soils that receive high-OM inputs have greater labile $\mathrm{C}$ pools, higher microbial activity and higher soil $\mathrm{N}$ supplying power compared to solely mineral fertilized soil (Burger and Jackson 2003).

\section{Charcoal plus mineral fertilization}

The synergistic effects if both charcoal plus mineral fertilizers were applied, doubled the cumulative grain yield of four harvests, but this study insufficiently explains the improved crop performance. Only extractable Al concentrations were found to be significantly lower in charcoal amended and mineral fertilized soil in comparison to mineral fertilized soil alone. Charcoal application increased legume production in a study by Topoliantz et al. (2005) due to decreased soil acidity and exchangeable $\mathrm{Al}$ but increased $\mathrm{Ca}$ and $\mathrm{Mg}$ availability. Reactive $\mathrm{Al}$ and $\mathrm{Fe}$ surfaces can form complexes with SOM, reducing the CEC but blocking these sites will reduce the capacity of soil to fix phosphate and sulphate. Increased SOM may also stimulate desorption of phosphate and sulphate by acting as a competing anion (Duxbury et al. 1989). Aluminum can reduce crop production severely (Sierra et al. 2003).

Lehmann et al. (2003) found decreasing N availability in the Ferralsol similar to ADE, but increased uptake of $\mathrm{P}, \mathrm{K}, \mathrm{Ca}$, zinc ( $\mathrm{Zn}$ ), and cupper $(\mathrm{Cu})$ by plants after higher charcoal additions. The application of charcoal significantly reduced leaching of applied mineral fertilizer $\mathrm{N}$. The increased ratio of uptake to leaching due to charcoal application indicates a high efficiency of nutrients applied with charcoal (Lehmann et al. 2003). In this study, we were not able to statistically prove increased availability of soil nutrient contents but in spite of significantly higher nutrient export by means of yield withdrawal, the available nutrient contents remained as high or higher in soils receiving charcoal than only mineral fertilized soils (Fig. 4). The withdrawal of $\mathrm{P}$ and $\mathrm{K}$ due to grain yield removal offset the additional plant available $\mathrm{P}$ and $\mathrm{K}$ supplied by the charcoal (Table 1) by a factor of two.

Microbial immobilization is described as an important mechanism to retain $\mathrm{N}$ in those soils highly affected by leaching (Bengtsson et al. 2003; Burger and Jackson 2003). They conclude that greater $\mathrm{C}$ availability stimulate microbial activity resulting in greater $\mathrm{N}$ demand, promoting immobilization, and recycling of $\mathrm{NO}_{3}$. Steiner et al. (2004a) found increased microbial reproduction rates after glucose addition in soils amended with charcoal, although not showing higher soil respiration rates. This indicates a low-biodegradable SOM content but sufficient soil nutrient contents to support microbial population growth. This difference between low-soil respiration and highmicrobial population growth potential is one of the characteristics of ADE (Steiner et al. 2004a).

Organic amendments (chicken manure)

In the case of $\mathrm{CM}$ the soil nutrient levels remained high during the entire study period 
(four harvests), although the quantity of nutrients applied as CM was not comparable to the amount applied as mineral fertilizer (Table 1). Duxbury et al. (1989) emphasizes the importance of organic P for plant growth in soils with reduced total $\mathrm{P}$ contents and high-phosphate adsorption capacity. Potassium and $\mathrm{N}$ are commonly quickly lost due to leaching and uptake by crops, $\mathrm{N}$ might in addition be lost by denitrification (Brady and Weil 2001). Without additional OM application no differences could be detected in the soil $\mathrm{K}$ and $\mathrm{N}$ contents due to mineral fertilization. $\mathrm{CM}$ significantly increased soil $\mathrm{K}$ contents until the end of the experiment although a large portion of its original soil contents was lost and exported during the four cropping cycles. Nitrogen limitation seemed to be of minor importance compared to $\mathrm{P}$ and $\mathrm{K}$. The initial $\mathrm{CM}$ application increased the soil $\mathrm{N}$ contents only for a short time, whereas productivity was sustained over the four cropping cycles. Elimination of exchangeable Al (from $63.8 \mathrm{mg} \mathrm{kg}^{-1}$ on the control plots) was already observed after the first cropping cycle and acidity continuously declined during the four cropping cycles (from 1.4 on control plots to 0.9 to 0.4 to 0.03 at $1 \mathrm{st}, 2 \mathrm{nd}$, and 4 th harvest, respectively). Materechera and Mkhabela (2002) measured a liming effectiveness of $\mathrm{CM}$ of $26 \%$ compared to lime. They conclude that the proton consuming ability of humic materials might have reduced acidity in their study. The slow reduction of acidity might be explained by the steady formation of organic material with functional groups such as carboxyl and phenolic groups during decomposition and by the low solubility of $\mathrm{CaCO}_{3}$.

\section{Conclusion}

In our experiment plant biomass production sharply decreased within 1 year when only mineral fertilizer was applied, but could be maintained for a longer period of time when $\mathrm{OM}$ was added. Soils fertilized with CM lost their initially high $\mathrm{N}$ and $\mathrm{K}$ contents during the four cropping cycles but remained fertile after the 4th harvest compared to other $\mathrm{OM}$ or inorganic fertilizer additions and had significantly increased crop production even without further input. $\mathrm{pH}$ seemed to be important to ensure high productivity. The charcoal additions proved to sustain fertility if an additional nutrient source is given. Even though significantly more nutrients $(\mathrm{P}, \mathrm{K}$, $\mathrm{Ca}, \mathrm{Mg}$, and $\mathrm{N}$ ) were exported from the charcoal plots, the available nutrient contents of the soil did not decrease in comparison to just mineral fertilized plots.

The losses of soil C were highest on CM (27\%) and compost $(27 \%)$ treated plots, followed by soils amended with litter $(26 \%)$, and the control (25\%) whereas the charcoal amended plots lost only 8 and $4 \%$ of their soil $\mathrm{C}$ content if mineral fertilized or not fertilized, respectively. The resilience of soil $\mathrm{C}$ in charcoal amended plots showed the refractory nature of charcoal. A combination of charcoal and CM might mimic the favorable properties of Terra Preta best.

We propose that charcoal applications can improve soil chemical, biological, and physical properties in various ways causing the observed significant increase in crop production. It is difficult to isolate single mechanisms, which were responsible for this increase. Further research is needed to discern the mechanisms of fertility enhancement and optimize charcoal use for soil amelioration.

Acknowledgments The research was conducted within SHIFT ENV 45, a German-Brazilian cooperation and financed by the Bundesministerium für Bildung und Forschung (BMBF), Germany and Conselho Nacional de Desenvolvimento Científico e Tecnológico (CNPq), Brazil (BMBF No. 0339641 5A, CNPq 690003/98-6). A financial contribution was given by the doctoral scholarship program of the Austrian Academy of Sciences. We are grateful for the fieldworkers' help particularly Luciana Ferreira da Silva and Franzisco Aragão Simão and the laboratory technician Marcia Pereira de Almeida. Critical comments and help were given by Prof. Dr. William I. Woods, Dr. Bruno Glaser, Jago Birk, and Heiko Grosch.

\section{References}

Baldock JA, Smernik RJ (2002) Chemical composition and bioavailability of thermally altered Pinus resinosa (Red pine) wood. Org Geochem 33:1093-1109

Bengtsson G, Bengtson P, Månsson KF (2003) Gross nitrogen mineralization-, immobilization-, and nitrification rates as a function of soil $\mathrm{C} / \mathrm{N}$ ratio and microbial activity. Soil Biol Biochem 35:143-154

Box GEP, Cox DR (1964) An analysis of transformations. J R Stat Soc Ser B.26:211-252 
Brady NC, Weil RR (2001) The nature and properties of soils. Prentice Hall, Englewood Cliffs, NJ

Burger M, Jackson LE (2003) Microbial immobilization of ammonium and nitrate in relation to ammonification and nitrification rates in organic and conventional cropping systems. Soil Biol Biochem 35:29-36

Cheng CH, Lehmann J, Thies JE, Burton SD, Engelhard MH (2006) Oxidation of black carbon by biotic and abiotic processes. Org Geochem 37:1477-1488

Claessen MEC, Barreto WdO, Paula JLd, Duarte MN (1997) Manual de metodos de analise de solo. EMBRAPA, Rio de Janeiro, p 212

Correia FWS, Lieberei R (1998) Agroclimatological information about the experimental field of the SHIFT-area, ENV 23, 42, 45, 52. In: Lieberei R, Biachi H, Voss K (eds) Third SHIFT workshop, Manaus, March 1998, 1998. BMBF, Germany, pp 389-396

Denevan WM (1996) A bluff model of riverine settlement in prehistoric Amazonia. Ann Assoc Am Geogr 86(4):654-681

Duxbury JM, Smith MS, Doran JW, Jordan C, Szott L, Vance E (1989) Soil organic matter as a source and a sink of plant nutrients. In: Coleman DC, Oades JM, Uehara G (eds) Dynamics of soil organic matter in tropical ecosystems. University of Hawaii Press, Honolulu, pp 33-67

Fageria NK (1998) Manejo da calagem e adubacao do arroz. Embrapa Arroz e Feijao, Santo Antonio de Goias, GO, pp 67-79

FAO (1990) Soil map of the world, revised legend. FAO, Rome, Italy

Fearnside PM (1997) Greenhouse gases from deforestation in Brazilian Amazinia: net committed emissions. Clim Chang 35:321-360

Fearnside PM, Lima PM, Graça A, Rodrigues FJA (2001) Burning of Amazonian rainforest: burning efficiency and charcoal formation in forest cleared for cattle pasture near Manaus, Brazil. For Ecol Manage 146:115128

Giardina CP, Sanford RL, Dockersmith IC, Jaramillo VJ (2000) The effects of slash burning on ecosystem nutrients during the land preparation phase of shifting cultivation. Plant Soil 220:247-260

Glaser B, Guggenberger G, Haumaier L, Zech W (2001a) Persistence of soil organic matter in archaeological soils (Terra Preta) of the Brazilian Amazon region. In: Rees RM, Ball BC, Campbell CD, Watson CA (eds) Sustainable management of soil organic matter. CABI Publishing, Wallingford, pp 190-194

Glaser B, Haumaier L, Guggenberger G, Zech W (2001b) The "terra preta" phenomenon: a model for sustainable agriculture in the humid tropics. Naturwissenschaften 88:37-41

Glaser B, Lehmann J, Zech W (2002) Ameliorating physical and chemical properties of highly weathered soils in the tropics with charcoal-a review. Biol Fertil Soils 35:219-230

Goldammer JG (1993) Historical biogeography of fire: tropical and subtropical. In: Crutzen PJ, Goldammer JG (eds) Fire in the environment: the ecological atmospheric, and climatic importance of vegetation fires. Wiley, New York, pp 297-314

Hölscher D, Ludwig B, Möller RF, Fölster H (1997a) Dynamic of soil chemical parameters in shifting agriculture in the Eastern Amazon. Agric Ecosyst Environ 66:153-163

Hölscher D, Möller RF, Denich M, Fölster H (1997b) Nutrient input-output budget of shifting agriculture in Eastern Amazonia. Nutr Cycl Agroecosys 47:49-57

Hughes RF, Kauffman JB, Cummings DL (2000) Fire in the Brazilian Amazon 3. Dynamics of biomass, C, and nutrient pools in regenerating forests. Oecologia 124:574-588

Kleinman PJA, Pimentel D, Bryant RB (1995) The ecological sustainability of slash-and-burn agriculture. Agric Ecosyst Environ 52:235-249

Kuhlbusch TA, Lobert JM, Crutzen PJ, Warneck P (1991) Molecular nitrogen emissions from denitrification during biomass burning. Nature 351:135-137

Kuhlbusch TAJ, Crutzen PJ (1995) Toward a global estimate of black carbon in residues of vegetation fires representing a sink of atmospheric $\mathrm{CO} 2$ and a source of O2. Global Biogeochem Cycles 9:491-501

Lehmann J, Campos CV, Macedo JLV, German L (2004) Sequential fractionation and sources of $\mathrm{P}$ in Amazonian dark earths. In: Glaser B, Woods WI (eds) Amazonian dark earths: exploration in time and space. Springer Verlag, Heidelberg, pp 113-123

Lehmann J, da Silva JP Jr, Rondon M, Cravo MdS, Greenwood J, Nehls T, Steiner C, Glaser B (2002) Slash and char-a feasible alternative for soil fertility management in the central Amazon? In: Proceedings of the 17th world congress of soil science, Bangkok, Thailand, 14-21. 08. 2002, Ed T I U o S Sciences, pp 449-1449-12

Lehmann J, da Silva JP Jr, Steiner C, Nehls T, Zech W, Glaser B (2003) Nutrient availability and leaching in an archaeological Anthrosol and a Ferralsol of the Central Amazon basin: fertilizer, manure and charcoal amendments. Plant Soil 249:343-357

Lehmann J, Feilner T, Gebauer G, Zech W (1999) Nitrogen uptake of sorghum (Sorghum bicolor L.) from tree mulch and mineral fertilizer under high leaching conditions estimated by nitrogen-15 enrichment. Biol Fertil Soils 30:90-95

Lehmann J, Gaunt J, Rondon M (2006) Bio-char sequestration in terrestrial ecosystems - a review. Mitig Adapt Strateg Global Change 11:403-427

Lewis J, Vosti S, Witcover J, Ericksen PJ, Guevara R, Tomich T (2002) Alternatives to slash-and burn in Brazil. World Agroforestry Centre (ICRAF), Nairobi, pp 1100

Liang B, Lehmann J, Solomon D, Grossman J, O'Neill B, Skjemstad JO, Thies J, Luizão FJ, Petersen J, Neves EG (2006) Black carbon increases cation exchange capacity in soils. Soil Sci Soc Am J 70:1719-1730

Lima HN, Schaefer CER, Mello JWV, Gilkes RJ, Ker JC (2002) Pedogenesis and pre-Colombian land use of "Terra Preta Anthrosols" ("Indian black earth") of Western Amazonia. Geoderma 110:1-17 
Materechera SA, Mkhabela TS (2002) The effectiveness of lime, chicken manure and leaf litter ash in ameliorating acidity in a soil previously under black wattle (Acacia mearnsii) plantation. Bioresour Technol 859-816

McLean EO (1965) Aluminium. In: Black CA (ed) Methods of soil analysis part 2: chemical and microbiological properties. Am. Soc. Agron, Madison, pp 986-994

Mehlich A (1984) Mehlich-3 Soil test extractant: a modification of Mehlich-2 extractant. Commun Soil Sci Plant Anal 15:1409-1416

Ogawa M (1994) Symbiosis of people and nature in the tropics. Farming Jp 28(5):10-30

Olsen SR, Sommers LE (1982) Phosphorus. In: Page AL, Miller RH, Keeney DR (eds) Methods of soil analyses: part 2 chemical and microbiological properties. Am. Soc. Agron, Wisconsin, pp 403-430

Renck A, Lehmann J (2004) Rapid water flow and transport of inorganic and organic nitrogen in a highly aggregated tropical soil. Soil Sci 169:330-341

Sanchez P (1976) Properties and management of soils in the tropics. Wiley, New York

Sierra J, Noël C, Dufour L, Ozier-Lafontaine H, Welcker C, Desfontaines L (2003) Mineral nutrition and growth of tropical maize as affected by soil acidity. Plant Soil 252:215-226

Silva-Forsberg MC, Fearnside PM (1995) Agricultural management of caboclos of the Xingu river: a starting point for sustaining populations in degraded areas in the Brazilian Amazon. In: Parrotta JA, Kanashiro M (eds) Management and rehabilitation of degraded lands and secondary forests in Amazonia. International Institute of Tropical Forestry, Rio Piedras, pp 90-95

Silvester-Bradley R, Oliveira LAD, Filho JADP, John STV (1980) Nodulation of legumes, nitrogenase activity of roots and occurrance of nitrogen-fixing
Azospirillum spp. in representative soils of central Amazonia. Agro-Ecosyst 6:249-266

Sombroek WG, Nachtergaele FO, Hebel A (1993) Amounts, dynamics and sequestering of carbon in tropical and subtropical soils. Ambio 22:417-426

Steiner, Teixeira WG, Lehmann J, Zech W (2004a) Microbial response to charcoal amendments of highly weathered soils and amazonian dark earths in central Amazonia-preliminary results. In: Glaser B, Woods WI (eds) Amazonian dark earths: explorations in space and time. Springer Verlag, Heidelberg, pp 195-212

Steiner C, Teixeira WG, Zech W (2004b) Slash and char: an alternative to slash and burn practiced in the Amazon basin. In: Glaser B, Woods WI (eds) Amazonian dark earths: explorations in space and time. Springer Verlag, Heidelberg, pp 183-193

Tiessen H, Cuevas E, Chacon P (1994) The role of soil organic matter in sustaining soil fertility. Nature 371:783-785

Topoliantz S, Ponge J-F, Ballof S (2005) Manioc peel and charcoal: a potential organic amendment for sustainable soil fertility in the tropics. Biol Fertil Soils 41:1521

Walinga I (1995) Digestion in tubes with H2SO4-salicylic acid-H2O2 and selenium and determination of $\mathrm{Ca}, \mathrm{K}$, $\mathrm{Mg}, \mathrm{N}, \mathrm{Na}, \mathrm{P}, \mathrm{Zn}$. In: Walinga I, Lee JJvd, Houba VJG, Vark Wv, Novozamsky I (eds) Plant analysis manual. Kluwer Academic Publishers, Dordrecht, The Netherlands

Zech W, Haumaier L, Hempfling R (1990) Ecological aspects of soil organic matter in the tropical land use. In: McCarthy P, Clapp C, Malcolm RL, Bloom PR (eds) Humic substances in soil and crop sciences; selected readings. American Society of Agronomy and Soil Science Society of America, Madison, pp 187-202 